\title{
Germination Ecology of Wild Onion: a Rainfed Crop Weed ${ }^{1}$
}

\author{
Ecologia da Germinação de Cebola Selvagem: uma Planta Daninha de Sequeiro
}

\author{
TANVEER, A. ${ }^{2}$, SIBTAIN, M. ${ }^{2}$, JAVAID, M.M. ${ }^{3}$, and ALI, H.H. ${ }^{4}$
}

\begin{abstract}
Asphodelus tenuifolius is becoming a more common weed in rain-fed area in Pakistan. Laboratory and greenhouse experiments were conducted to determine the effect of different environmental factors on germination and emergence of $A$. tenuifolius. Results showed that $A$. tenuifolius can tolerate a wide range of varying environmental factors. Greatest percentage of germination $(80 \%)$ was recorded at $15^{\circ} \mathrm{C}$ constant temperature; however, considerable germination occurred at 20 and $25{ }^{\circ} \mathrm{C}$. Light for $10 \mathrm{~h}$ photoperiod stimulate germination of Asphodelus tenuifolius compared with complete darkness. Germination was totally inhibited at osmotic stress higher than $-0.8 \mathrm{MPa}$. There was no significant difference in germination at $\mathrm{pH} 6$ to 8; however, there was a slightly decrease at $\mathrm{pH} 9$, compared with distilled water. Asphodelus tenuifolius was very sensitive to salinity; however, a few seeds of A. tenuifolius were able to germinate even at $150 \mathrm{mM} \mathrm{NaCl}$ concentration. Greatest emergence occurred with seed placed at soil surface and emergence decreased with increase in burial depth. No emergence occurred from $4 \mathrm{~cm}$ or greater. This information may aid in developing tools and strategies for management.
\end{abstract}

Keywords: Asphodelus tenuifolius, temperature, water stress, salt stress, $\mathrm{pH}$, seedling emergence, seeding depth.

RESUMO - Asphodelus tenuifolius está se tornando uma planta daninha cada vez mais comum em plantio de sequeiro no Paquistão. Foram realizados experimentos no laboratório e na estufa para avaliar a influência de diferentes fatores ambientais na germinação e emergência da A. tenuifolius. Os resultados mostraram que a A. tenuifolius é capaz de tolerar uma ampla gama de fatores ambientais diferentes. A porcentagem máxima de germinação (80\%) foi registrada a $15^{\circ} \mathrm{C}$ de temperatura constante. No entanto, houve germinação considerável em $20^{\circ} \mathrm{C}$ e $25^{\circ} \mathrm{C}$. A inserção de luz em $10 \mathrm{~h}$ de fotoperiodo estimula a germinação da Asphodelus tenuifolius, o que não ocorre com escuridão completa. A germinação foi totalmente inibida quando houve estresse osmótico maior que -0, $8 \mathrm{MPa}$. Não houve diferença significativa na germinação com $\mathrm{pH}$ de 6 a 8, porém, houve uma pequena redução com pH 9, tendo como referência a água destilada. Asphodelus tenuifolius se mostrou muito sensivel à salinidade, mas, ainda assim, algumas sementes germinaram com concentração de $150 \mathrm{mM}$ de $\mathrm{NaCl}$. Ocorreu maior emergência quando as sementes foram plantadas na superficie do solo. E, na medida em que o enterramento se tornava mais profundo, sua emergência reduzia. Não foram observadas emergências a partir de 4 centimetros de profundidade. Estas informações podem auxiliar no desenvolvimento de ferramentas e estratégias para seu manejo.

Palavras-chave: Asphodelus tenuifolius, temperatura, estresse hídrico, estresse salino, pH, emergência de plântulas, profundidade de semeadura.

\section{INTRODUCTION}

Wild onion (Asphodelus tenuifolius) is a very harmful and noxious weed to chickpea, wheat, mustard, linseed and lentil in Pakistan and
India (Ponia et al., 2001; Tiwari et al., 2001; Nasir \& Sultan, 2004), due to its high competitive ability, greater production of seeds and reproduction potential. It is native to the Mediterranean region, but it is widespread,

1 Recebido para publicação em 23.7.2013 e aprovado em 23.1.2014.

2 University of Agriculture Faisalabad, Pakistan, ${ }^{3}$ Department of Agronomy, University College of Agriculture, University of Sargodha, Pakistan, <mmjavaid@uos.edu.pk>; ${ }^{4}$ College of Agriculture and Environmental Sciences, The Islamia University of Bahawalpur, Pakistan. 
extending from the Mediterranean region east through the Arabian Peninsula to almost 17 countries around the world (Holm et al., 1977). It is an annual herb, $15-50 \mathrm{~cm}$ tall with linear, acute, sheathing at the base, with fine puberulous leaves. The plant is eaten raw as well as in cooked form, particularly during famine. The seeds are sharply trigons, and black in colour.

Seed germination, an important factor in determining weed success, is regulated by many environmental factors, e.g. light, temperature, soil $\mathrm{pH}$, soil salinity, weed seed size and available moisture (Koger et al., 2004; Harrison et al., 2007; Chauhan \& Johnson, 2008a). Factors like acidity, water and salinity are not limiting; temperature is the major key for successful weed seed germination (Martinkova et al., 2006), and within same species it may be different for varied genotypes (Chauhan \& Johnson, 2008a; Harrington, 2009; Wang et al., 2009; Malik et al., 2010; Masin et al., 2010; Gorai et al., 2011). Seeds of some weeds germinate well in the dark and with light; and broad leaf weeds having small seeds are photoblastic (Widderick et al., 2004; Zhou et al., 2005).

Water stress is always a very important attribute to inhibit seed germination (Norsworthy \& Oliveira, 2006). Various species behave differently during water uptake in seed imbibition on their germination process (Chauhan \& Johnson, 2008b). Ability to germinate under condition of moisture stress may enable weed to take advantage of the condition that limits the growth of other species. The impact of soil moisture on germination varies among weed species; and field condition may differ spatially and temporally, depending on rainfall, temperature, and type of soil. Soil $\mathrm{pH}$ is another important environmental factor affecting seed germination of various weeds. Seeds of some weeds can germinate over a broad $\mathrm{pH}$ range (Chachalis et al., 2008; Chejara et al., 2008), while other weeds can germinate well in acidic soil conditions (Fried et al., 2008).

Salt stress is a major constraint in crop or weed production worldwide. Physiological processes in some weeds are negatively affected by soil salinity (DiTommaso, 2004; Chauhan \& Johnson, 2008b). High salt concentration inhibits the germination of many weed seeds and it ultimately leads towards death (Koger et al., 2004; Pahlevani et al., 2008; Nemati et al., 2011), with some exceptions as a few types of weed seeds show tolerance to high salt concentrations (Chauhan \& Johnson, 2008c). Seed burial depth also affects its germination and seedling emergence (Koger et al., 2004; Mennan \& Ngouajio, 2006). Weed seed location in the soil seed bank influences germination, emergence and vertical seed distribution in the soil (Norsworthy \& Oliveira, 2006).

Biological and ecological information, specifically germination ecology of a specific weed, is necessary to optimize weed control and maximize the efficiency of management tactics (Bhowmik, 1997). In order to understand the expansion of the geographic range of A. tenuifolius in Pakistan, we need to learn how their seeds respond to varied climatic factors. To date, no specific research on the germination ecology of these weeds has been conducted. The objectives of this study are to determine the effects of temperature, light, salt and osmotic stress, $\mathrm{pH}$ and burial depth on A. tenuifolius seed germination and seedling emergence.

\section{MATERIALS AND METHODS}

\section{Seed collection}

Experiments were conducted at the Department of Agronomy, University of Agriculture Faisalabad, Pakistan under laboratory and greenhouse conditions during 2009. In March-April 2009 mature wild onion (A. tenuifolius) plants were collected from several farmer fields in district Bhakkar ( $31^{\circ} \mathrm{N}$, latitude and $71^{\circ} \mathrm{E}$, longitude), Pakistan and a composite sample was prepared. A working sample was drawn from this composite sample. Then seeds were removed and cleaned manually and dried at $25{ }^{\circ} \mathrm{C}$ (room temperature) for 20 days and stored in small cloth bags until used in all experiments.

\section{Experimental methodology}

Germination was determined by placing 25 seed evenly in a $9 \mathrm{~cm}$ diameter Petri plate containing filter paper Whatman No. 10, 
moistened with $5 \mathrm{~mL}$ distilled water or a treatment solution. Seed of A. tenuifolius were surface sterilized by soaking in $10 \%$ sodium hypochlorite ( $\mathrm{NaOCl}$ ) for $5 \mathrm{~min}$, followed by five rinses with distilled water before the start of each germination trial. Petri plates were sealed with Para film to reduce the water loss. All the experiments (except for the temperature experiment) were conducted at $15^{\circ} \mathrm{C}$ temperature with $10 \mathrm{~h}$ photoperiod (except for the light experiment). Fluorescent lamps were used to produce a photosynthetic photon flux density of $200 \mu \mathrm{mol} \mathrm{m}^{-2} \mathrm{~s}^{-1}$ for all the experiments, except for the dark treatment in the light experiment. Germinated seed with a radicle at least $2 \mathrm{~mm}$ long were counted and removed daily for a period of $3 \mathrm{wk}$. Petri plates assigned to complete darkness treatment were opened in a dark room with a safe green light.

\section{Effect of temperature}

Seeds were incubated at 15, 20 and $25{ }^{\circ} \mathrm{C}$ for $3 \mathrm{wk}$ to determine the optimum temperature for germination. Petri plates were kept in a germinator (Seedburo Equipment Company, Chicago, IL, USA) and the temperatures were maintained constant.

\section{Effect of light}

To evaluate the effect of light on A. tenuifolius germination, seeds were placed in Petri plates and immediately wrapped with aluminum foil to ensure no light penetration. Other treatment was left uncovered to allow $10 \mathrm{~h}$ light exposure. Light was provided by fluorescent over-head bulbs set for 10-h light, 14-h dark regime with a photosynthetic photon flux density of $200 \mu \mathrm{m} \mathrm{m}^{-2} \mathrm{~s}^{-1}$.

\section{Effect of drought stress}

Seed germination of $A$. tenuifolius was checked against drought stress using aqueous solutions of different osmotic potential 0 (Control) -0.2,-0.4,-0.6, -0.8,-1.0 MPa. These aqueous solutions were prepared with PEG 6000 (Polyethylene glycol) by using the Michel \& Kaufman (1973) equation as under:

Water potential $=-\left(1.18 \times 10^{-2}\right) \mathrm{C}-(1.18 \times$ $\left.10^{-4}\right) \mathrm{C}^{2}+\left(2.67 \times 10^{-4}\right) 18 \mathrm{CT}+\left(8.39 \times 10^{-7}\right) \mathrm{C}^{2} \mathrm{~T}$ where $\mathrm{C}$ is the concentration of PEG $\left(\mathrm{g} \mathrm{kg}^{-1}\right.$ distilled water) and $\mathrm{T}$ is temperature $\left({ }^{\circ} \mathrm{C}\right)$.

After preparing the solutions osmotic potential was confirmed by osmometer (vapour pressure type), model 5520; Wescor, Logan, UT, USA. Control treatment was carried out with distilled water.

\section{Effect of pH}

To examine the effect of $\mathrm{pH}$ on germination, buffer solutions of $\mathrm{pH} 6$ to 9 were prepared according to the method described by Chacahlis \& Reddy (2002). A 2-mM solution of MES [2-(N-morpholino) ethanesulfonic acid] was adjusted to $\mathrm{pH} 6$ with $1 \mathrm{~N}$ hydrogen chloride $(\mathrm{HCl})$ or sodium hydroxide $(\mathrm{NaOH})$. A 2-mM solution of HEPES [N-(2-hydroxy-methyl) piperazine- $\mathrm{N}$-(2-ethanesulfonic acid)] was adjusted to $\mathrm{pH} 7$ or 8 with $1 \mathrm{~N} \mathrm{NaOH}$. A pH 9 buffer was prepared with 2-mM TRICINE [NTris (hydroxymethyl) methylglycine] and adjusted with $1 \mathrm{~N} \mathrm{NaOH}$. Unbuffered deionized water $(\mathrm{pH}$ 6.2) was used as a control.

\section{Effect of salt stress}

Germination of $A$. tenuifolius seeds was checked against different levels of sodium chloride 50, 100, 150, $200 \mathrm{mM}$. While in control treatment distilled water was used.

\section{Effect of seeding depth}

This experiment was carried out in green house. Pots having $25 \mathrm{~cm}$ diameter were filled with sand $(0.5 \mathrm{~kg}$ per pot). Twenty five seeds of A. tenuifolius per pot were placed at soil surface or within the soil from $0 \mathrm{~cm}$ (surface placement) 1, 2, 3, 4, 5, $6 \mathrm{~cm}$ burial depths. Every pot was initially irrigated with $100 \mathrm{ml}$ of distilled water. Greenhouse temperatures were $15 \pm 2{ }^{\circ} \mathrm{C}$ during the day and $10 \pm 2{ }^{\circ} \mathrm{C}$ at night with a $10-\mathrm{h}$ photoperiod (200 to $500 \mu \mathrm{mol}$ photons $\left.\mathrm{m}^{-2} \mathrm{~s}^{-1}\right)$. Pots were left opened and watered as needed to maintained adequate soil moisture. Each pot has a hole at the bottom for drainage. Seedlings were considered emerged when a cotyledon was visible at the soil surface. Seedling emergence was recorded daily for 21 days. 
Germination/emergence index (GI/EI) was calculated by following formula used by Association of Official Seed Analysis (AOSA, 1990).

$$
G l \text { or } E I=\frac{\text { No of germinate or emerged seeds }}{\text { Days of first count }}+\ldots
$$

$$
+\frac{\text { No of germinated or emerged seeds }}{\text { Days of final count }}
$$

It was noted when the germination/ emergence of a treatment started, i.e. when first seed of $A$. tenuifolius was germinated or emerged. Coolbear et al. (1984) formula was used to determine time to $50 \%$ germination/ emergence.

$$
T_{50} \text { or } E_{50}=t_{i}+\frac{\left(\frac{N}{2}-n_{i}\right)\left(t_{j}-t_{i}\right)}{\left(n_{j}-n_{i}\right)}
$$

where $N$ is the final number of germinated or emerged seed and $n_{j}$ and $n_{i}$ are the cumulative number of seed germinated by adjacent counts at times $t_{j}$ (day) and $t_{i}$, (day) respectively, when $n_{i}<\mathrm{N} / 2<n_{j}$

Mean germination or emergence time (MGT or MET) was calculated according to the equation of Ellis \& Roberts (1981):

$$
M G T \text { or } M E T=\frac{\sum D n}{\sum n}
$$

where $n$ is the number of seed that had germinated on day $D$ and $D$ is the number of days counted from the beginning of germination experiment. The germination or emergence index ( $G I$ or $E$ ) was calculated as described by the Association of Official Seed Analysis (AOSA, 1983) using the following formula:

\section{Statistical analysis}

A completely randomized design with four replications was used in all experiments. Data were subjected to analysis of variance (ANOVA) with the use of SAS (2002). The model structure of ANOVA was $Y_{i j}=\mu+T_{i+\in i j}$ where $Y_{i j}$ is the observed response variable, $\mu$ is an overall mean, $T_{i}$ is the explanatory variable and $\epsilon_{i j}$ is the error. The significant difference among treatment means were identified by using Fisher, LSD at $\mathrm{P}<0.05$ (Steel et al., 1997). A square-root arcsine transformation was used to stabilize the variances for percentage data before analysis (Bartlett, 1947). Nonlinear regression analysis was used to determine how $\mathrm{NaCl}$, osmotic stress or burial depth affected percentage germination or emergence. Germination (\%) values at different concentrations of $\mathrm{NaCl}$ and osmotic potential were fitted to a functional threeparameter logistic model using Sigma Plot 2008 (version 11.0). The model fitted was $G(\%)=G_{\max } /\left[1+\left(x / x_{50}\right)^{g}\right]$, where $G$ is the total germination $(\%)$ at concentration $x, G_{\max }$ represents maximum germination (\%), $x_{50}$ is the $\mathrm{NaCl}$ concentration or osmotic potential for $50 \%$ inhibition of the maximum germination and $g$ indicates the slope. A three parameter logistic model $\left\{E(\%)=E_{\max } /[1+(x)\right.$ $\left.\left.\left.x_{50}\right)^{e}\right]\right\}$ was fitted to A. tenuifolius seedling emergence $(\%)$ obtained at different burial depth of 0 to $6 \mathrm{~cm}$. where $E$ is the total seedling emergence (\%) at burial depth $x, E_{\max }$ is the greatest seedling emergence (\%), $x_{50}$ is the burial depth for $50 \%$ inhibition of the greatest seedling emergence and $e$ indicates the slope. The t-test was used to assess significant difference between light and dark treatment in the light experiment.

\section{RESULTS AND DISCUSSION}

\section{Effect of temperature}

Asphodelus tenuifolius germination was tested against varying temperature regimes from 15 to $25^{\circ} \mathrm{C}$ with an interval of $5{ }^{\circ} \mathrm{C}$. Asphodelus. tenuifolius germination was significantly affected by different temperatures; and greatest $A$. tenuifolius germination $(80 \%)$ was recorded at $15{ }^{\circ} \mathrm{C}$ (Figure 1). However germination of A. tenuifolius decreased with increasing temperature, and lowest (32\%) was noted at $25^{\circ} \mathrm{C}$ (Figure 1). The starting time for A. tenuifolius germination was lowest at $15^{\circ} \mathrm{C}$ (2.75 days). However it increased with increasing temperature, i.e. A. tenuifolius took 3.00 and 4.00 days at $20^{\circ} \mathrm{C}$ and $25^{\circ} \mathrm{C}$, respectively, to start its germination (Table 1). Asphodelus tenuifolius took statistically 


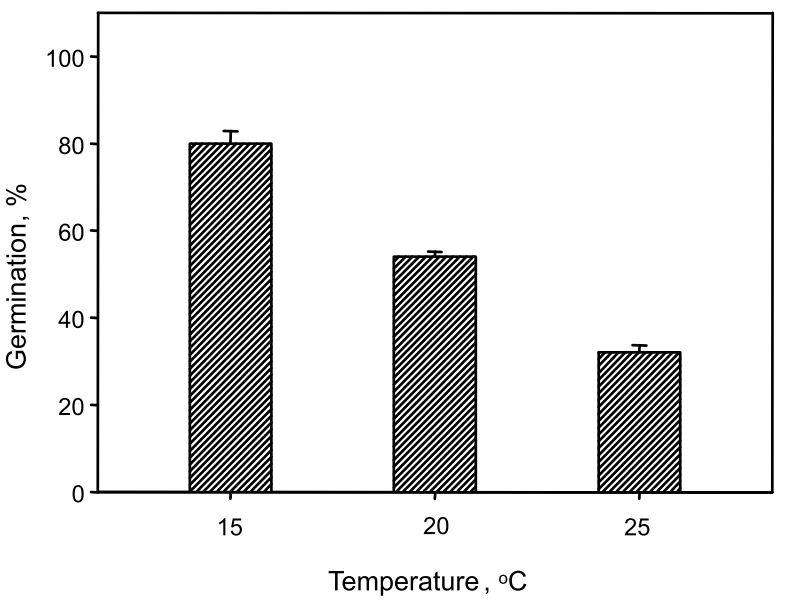

Vertical bars represent \pm standard error of the mean.

Figure 1 - Effect of temperature on A. tenuifolius seed germination (\%).

similar days to its $50 \%$ germination at $15^{\circ} \mathrm{C}$ (5.06 days) and at $20^{\circ} \mathrm{C}$ (4.91 days), however A. tenuifolius took greatest (7.75 days) at $25{ }^{\circ} \mathrm{C}$. Mean germination time of $A$. tenuifolius was highest ( 7.40 days) at $25^{\circ} \mathrm{C}$ and it was followed by 5.84 days at $15{ }^{\circ} \mathrm{C}$, however lowest (5.57 days) A. tenuifolius mean germination time was noted at $20^{\circ} \mathrm{C}$. Maximum (3.86) A. tenuifolius germination index was noted at $15{ }^{\circ} \mathrm{C}$ and it decreased with increasing temperature i.e. 2.62 at $20{ }^{\circ} \mathrm{C}$ and 1.22 at $25^{\circ} \mathrm{C}$ (Table 1).

Our findings show that $25^{\circ} \mathrm{C}$ temperature and above have negatively affected A. tenuifolius germination; and that chances of heavy A. tenuifolius infestation during chickpea crop emergence in October are less likely because temperature is about $25.9{ }^{\circ} \mathrm{C}$ in October. However, as temperatures decrease in November, December and January
(20 to $\left.13{ }^{\circ} \mathrm{C}\right)$, A. tenuifolius germination in chickpea may increase. Many researchers observed a significant effect of temperature on weed seeds germination (Kabat et al., 2007; Guma et al., 2010). Seed germination of Leptochloa chinensis and Cuscuta campestris was highest at $25^{\circ} \mathrm{C}$ and $30^{\circ} \mathrm{C}$, respectively (Benvenuti et al., 2004, 2005), however C. campestris seed germination was completely inhibited at $10{ }^{\circ} \mathrm{C}$. Similarly, Ingolia et al. (2008) observed 60 to $80 \%$ seed germination of Rorippa subumbellata at $24{ }^{\circ} \mathrm{C}$. Seeds of coolatai grass were reported to germinate over a wide range of temperature range from 5 to $45^{\circ} \mathrm{C}$; however germination percentage was very low above $40^{\circ} \mathrm{C}$ (Chejara et al., 2008).

\section{Effect of light}

Light in $10 \mathrm{~h}$ photoperiod resulted in highest germination percentage $(87 \%)$ of A. tenuifolius compared with complete darkness (0 hours light) that resulted in 78\% germination. Table 2 showed a non-significant effect of dark and light on A. tenuifolius time to start germination, time to $50 \%$ germination and mean germination time. However statistically significant and highest germination index (5.21) of A. tenuifolius was observed under light and lowest (4.54) was observed under darkness. The results of our experiments show that darkness did not significantly reduce $A$. tenuifolius germination and $78 \%$ germination under darkness shows that $A$. tenuifolius is less sensitive to darkness ( 0 hours of light) for its germination. It suggests that $A$. tenuifolius seeds can germinate well under dense crop canopy or under shade conditions, and this ability of $A$. tenuifolius seeds can pose a major threat to crop production. In contrast, light sensitivity of

Table 1 - Effect of varying temperature regimes on starting time of germination, time to $50 \%$ germination, mean germination time and germination index of $A$. tenuifolius

\begin{tabular}{|c|c|c|c|c|}
\hline Temperature & T-start \pm SE (days) & T-50 \pm SE (days) & MGT \pm SE (days) & GI \pm SE \\
\hline $15^{\circ} \mathrm{C}$ & $2.75 \mathrm{~b} \pm 0.25$ & $5.06 \mathrm{~b} \pm 0.12$ & $5.84 \mathrm{~b} \pm 0.08$ & $3.86 \mathrm{a} \pm 0.10$ \\
\hline $20^{\circ} \mathrm{C}$ & $3.00 \mathrm{~b} \pm 0.00$ & $4.91 \mathrm{~b} \pm 0.06$ & $5.57 \mathrm{c} \pm 0.02$ & $2.62 \mathrm{~b} \pm 0.05$ \\
\hline $25^{\circ} \mathrm{C}$ & $4.00 \mathrm{a} \pm 0.00$ & $7.75 \mathrm{a} \pm 0.14$ & $7.40 \mathrm{a} \pm 0.10$ & $1.22 \mathrm{c} \pm 0.06$ \\
\hline LSD $\leq 0.05$ & 0.46 & 0.36 & 0.24 & 0.24 \\
\hline
\end{tabular}

Values with same letters did not differ significantly at $\mathrm{P} \leq 0.05$. T-start $=$ starting time of germination, $\mathrm{T}-50=$ time to $50 \%$ germination, $\mathrm{MGT}=$ mean germination time, $\mathrm{GI}=$ germination index and $\mathrm{SE}=$ standard error . 
Borreria ocymoides (purple leaf button) (Chauhan \& Johnson, 2008e), Amaranthus spinosus (spiny amaranth) (Chauhan \& Johnson, 2009c) and Synedrella nodiflora (Chauhan \& Johnson, 2009b) was reported in different studies. Similar to our results Rao et al. (2008) and Wang et al. (2009) reported that germination of Beckmannia syzigachne (American sloughgrass) and Urena lobata (cadillo) seeds was not affected by darkness or light. Seeds of Eluesine indica (goosegrass) germinated well $(68.72 \%)$ under 12 hours of light and dark, compared with complete darkness (17-25\%) (Chauhan \& Johnson, 2008d).

\section{Effect of drought stress}

Asphodelus tenuifolius seed germination decreased from 87 to $8 \%$ as drought stress increased from 0 to $0.6 \mathrm{MPa}$. No germination of $A$. tenuifolius seeds was observed at $0.8 \mathrm{MPa}$ osmotic potential. Logistic model showed $50 \%$ inhibition in germination of $A$. tenuifolius seeds at -0.38 MPa osmotic potential (Figure 3).

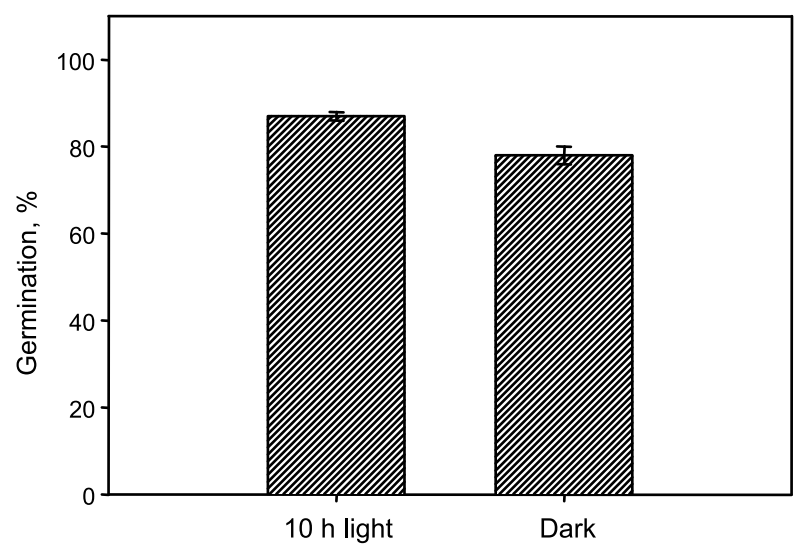

Vertical bars represent \pm standard error of the mean.

Figure 2 - Effect of dark/light on A. tenuifolius seed germination (\%).
Increase in time to start A. tenuifolius germination was noted with increased osmotic stress (From 0 to $-0.6 \mathrm{MPa}$ ) and $A$. tenuifolius seeds took most days (6.75 days) to start its germination at $0.6 \mathrm{MPa}$ osmotic stress (Table 3). Similar trend in time to obtain $50 \%$ germination and MGT was observed and $A$. tenuifolius took most days (9.94 and 8.81 days) at $-0.6 \mathrm{MPa}$, respectively (Table 3 ). Table 3 showed that (GI) decreased with increased levels of drought stress. The highest G.I was recorded with control (3.74) and lowest was recorded at -0.6 MPa drought stress (0.27).

Our results showed that moisture availability or rainfall is very important for A. tenuifolius germination, and that drought can adversely decreased A. tenuifolius

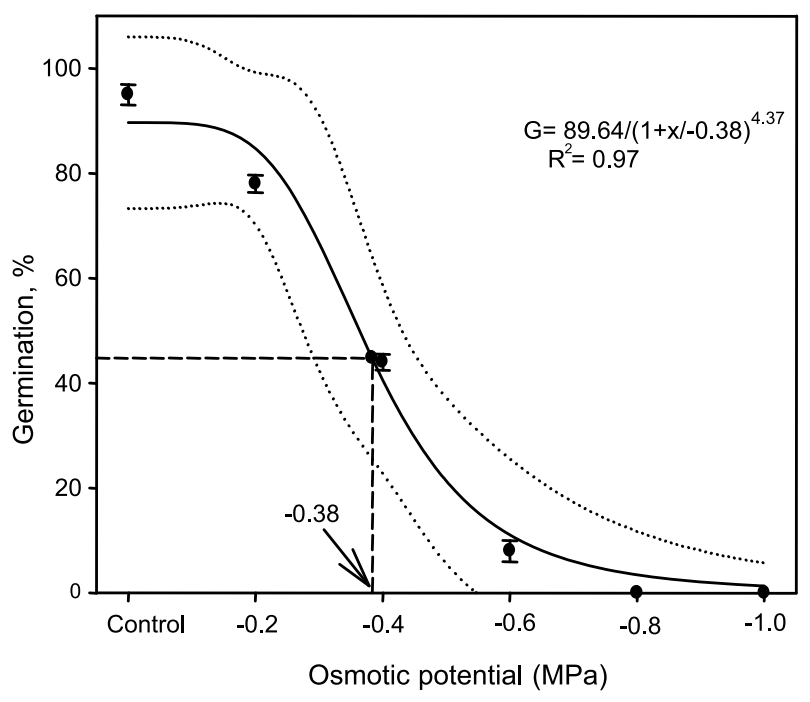

Vertical bars represent \pm standard error of the mean. Vertical dash line represents $\mathrm{X}$-axis value at $50 \%$ of greatest germination.

Figure 3 - Effect of water availability on A. tenuifolius seed germination (\%). The bold lines represent a three-parameter logistic model fitted to the data and dotted lines show 95\% confidence intervals.

Table 2 - Effect of dark/light on starting time of germination, time to 50\% germination, mean germination time and germination index of $A$. tenuifolius

\begin{tabular}{|c|c|c|c|c|}
\hline Light & T-start \pm SE (days) & T-50 \pm SE (days) & MGT \pm SE (days) & GI \pm SE \\
\hline $10 \mathrm{~h}$ light & $2.00 \pm 0.00$ & $4.71 \pm 0.20$ & $6.00 \pm 0.15$ & $5.21 \mathrm{a} \pm 0.07$ \\
\hline $0 \mathrm{~h}$ light & $2.00 \pm 0.00$ & $4.92 \pm 0.25$ & $5.96 \pm 0.16$ & $4.54 \mathrm{~b} \pm 0.07$ \\
\hline LSD $\leq 0.05$ & NS & NS & NS & 0.24 \\
\hline
\end{tabular}

Values with same letters did not differ significantly at $\mathrm{P} \leq 0.05$. NS $=$ non-significant, T-start $=$ starting time of germination, T-50 = time to $50 \%$ germination, $\mathrm{MGT}=$ mean germination time, $\mathrm{GI}=$ germination index and $\mathrm{SE}=$ standard error. 
Table 3 - Effect of water availability on starting time of germination, time to $50 \%$ germination, mean germination time and germination index of $A$. tenuifolius

\begin{tabular}{|c|c|c|c|c|}
\hline Drought stress $(\mathrm{MPa})$ & T-start \pm SE (days) & T-50 \pm SE (days) & MGT \pm SE (days) & GI \pm SE \\
\hline 0 (Control) & $5.00 \mathrm{c} \pm 0.00$ & $6.16 \mathrm{~b} \pm 0.05$ & $6.57 \mathrm{~b} \pm 0.03$ & $3.74 \mathrm{a} \pm 0.07$ \\
\hline-0.2 & $5.00 \mathrm{c} \pm 0.00$ & $9.31 \mathrm{a} \pm 0.18$ & $9.52 \mathrm{a} \pm 0.11$ & $2.21 \mathrm{~b} \pm 0.09$ \\
\hline-0.4 & $6.00 \mathrm{~b} \pm 0.00$ & $9.29 \mathrm{a} \pm 0.34$ & $9.78 \mathrm{a} \pm 0.10$ & $1.19 \mathrm{c} \pm 0.10$ \\
\hline-0.6 & $6.75 \mathrm{a} \pm 0.25$ & $9.94 \mathrm{a} \pm 1.36$ & $8.81 \mathrm{a} \pm 0.69$ & $0.27 \mathrm{~d} \pm 0.07$ \\
\hline-0.8 & $\mathrm{~N} / \mathrm{G}$ & $\mathrm{N} / \mathrm{G}$ & $\mathrm{N} / \mathrm{G}$ & $\mathrm{N} / \mathrm{G}$ \\
\hline-1.0 & $\mathrm{NG}$ & $\mathrm{N} / \mathrm{G}$ & $\mathrm{N} / \mathrm{G}$ & $\mathrm{N} / \mathrm{G}$ \\
\hline LSD $\leq 0.05$ & 0.39 & 2.18 & 1.08 & 0.25 \\
\hline
\end{tabular}

Values with same letters did not differ significantly at $\mathrm{P} \leq 0.05 . \mathrm{N} / \mathrm{G}=$ non-germinated, T-start $=$ starting time of germination, $\mathrm{T}-50=$ time to $50 \%$ germination, MGT = mean germination time, GI = germination index and $\mathrm{SE}=$ standard error.

germination. We further conclude that during the drier chickpea growing months A. tenuifolius germination would be restricted to low laying areas, where more moisture of summer rainfall is preserved in AugustSeptember. Similar response for seed germination of Eupatorium adenophorum (crofton weed); (Lu et al., 2006), Synedrella nodiflora (Chauhan \& Johnson, 2008b) and Eluesine indica (goosegrass) (Chauhan \& Johnson, 2008d) was recorded, i.e the seeds of these weeds are sensitive to different levels of drought stress.

Contrary to the above findings, seed germination of Hibiscus trionum (venice mallow); (Chachalis et al., 2008), Rapistrum rugosum (turnip weed); (Chauhan et al., 2006c) and Solanum sarrachoides (hairy night shade) (Zhou et al., 2005) was recorded under drought stress (low water potential). Similarly, in the studies of Chauhan \& Johnson (2008b), seed germination of indian crabgrass was inhibited at higher levels $(-1.0 \mathrm{MPa})$ of water stress, however southern crabgrass seeds germinated to some extent.

\section{Effect of pH}

Different levels of $\mathrm{pH}$ had a significant effect on $A$. tenuifolius seed germination and other germination related parameters. Asphodelus tenuifolius seeds exhibited highest (98\%) germination at $\mathrm{pH} 7$. Asphodelus tenuifolius seeds showed similar germination of $96 \%$ at pH levels of 6.00, 6.20, 6.50 and 7.50. Lowest germination of $A$. tenuifolius (82\%) was recorded at $\mathrm{pH} 9.00$ (Figure 4). Starting time of $A$. tenuifolius germination increased with increasing $\mathrm{pH}$ levels from 6.00 to 7.5 (2.00 to 5.00 days), however $\mathrm{pH}$ increase from 7.5 to 9.00 did not affect the starting time of A. tenuifolius germination (5.00 days). Asphodelus tenuifolius seeds took the lowest time to 50\% germination (3.91 days) and MGT

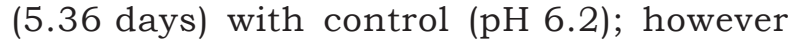
maximum time was taken at $\mathrm{pH}$ levels of 7.5 and 8.00. The highest GI (5.87) was measured with control and the lowest was measured at $\mathrm{pH}$ level 9.00 (2.82). However, $\mathrm{pH}$ levels of $7.5,8.00,8.5$ and 9.00 exhibited statistically similar GI of A. tenuifolius seeds (Table 4).

Our findings regarding the effect of $\mathrm{pH}$ on A. tenuifolius germination showed that A. tenuifolius can germinate under a wide

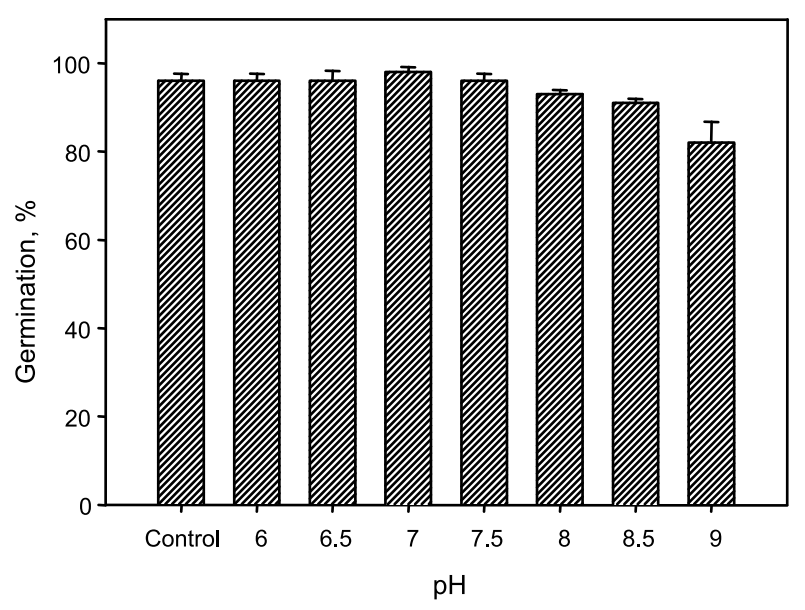

Vertical bars represent \pm standard error of the mean.

Figure 4 - Effect of pH on A. tenuifolius seed germination (\%). 
Table 4 - Effect of pH on starting time of germination, time to 50\% germination, mean germination time and germination index of A. tenuifolius

\begin{tabular}{|c|c|c|c|c|}
\hline $\mathrm{pH}$ & T-start $\pm \mathrm{SE}$ (days) & $\mathrm{T}-50 \pm \mathrm{SE}$ (days) & MGT $\pm \mathrm{SE}$ (days) & $\mathrm{GI} \pm \mathrm{SE}$ \\
\hline 6.2 (Control) & $2.00 \mathrm{~d} \pm 0.00$ & $3.91 \mathrm{~d} \pm 0.05$ & $5.36 \mathrm{f} \pm 0.17$ & $5.87 \mathrm{a} \pm 0.11$ \\
\hline 6.0 & $3.25 \mathrm{c} \pm 0.48$ & $5.44 \mathrm{c} \pm 0.02$ & $6.41 \mathrm{e} \pm 0.10$ & $4.06 \mathrm{~b} \pm 0.06$ \\
\hline 6.5 & $3.50 \mathrm{bc} \pm 0.50$ & $5.53 \mathrm{bc} \pm 0.02$ & $7.22 \mathrm{~d} \pm 0.14$ & $3.78 \mathrm{c} \pm 0.09$ \\
\hline 7.0 & $4.00 \mathrm{~b} \pm 0.00$ & $6.77 \mathrm{~b} \pm 0.56$ & $8.23 \mathrm{c} \pm 0.16$ & $3.39 \mathrm{~d} \pm 0.05$ \\
\hline 7.5 & $5.00 \mathrm{a} \pm 0.00$ & $8.81 \mathrm{a} \pm 0.76$ & $9.03 \mathrm{a} \pm 0.14$ & $3.00 \mathrm{e} \pm 0.01$ \\
\hline 8.0 & $5.00 \mathrm{a} \pm 0.00$ & $8.89 \mathrm{a} \pm 0.12$ & $8.77 \mathrm{ab} \pm 0.03$ & $2.96 \mathrm{e} \pm 0.05$ \\
\hline 8.5 & $5.00 \mathrm{a} \pm 0.00$ & $6.76 \mathrm{~b} \pm 0.56$ & $8.67 \mathrm{abc} \pm 0.10$ & $3.00 \mathrm{e} \pm 0.04$ \\
\hline 9.0 & $5.00 \mathrm{a} \pm 0.00$ & $6.32 \mathrm{bc} \pm 0.63$ & $8.37 \mathrm{bc} \pm 0.36$ & $2.82 \mathrm{e} \pm 0.08$ \\
\hline $\mathrm{LSD} \leq 0.05$ & 0.71 & 1.31 & 0.51 & 0.20 \\
\hline
\end{tabular}

Values with same letters did not differ significantly at $\mathrm{P} \leq 0.05$. T-start $=$ starting time of germination, $\mathrm{T}-50=$ time to $50 \%$ germination, MGT = mean germination time, GI = germination index and SE = standard error.

range of $\mathrm{pH}$, under various soil conditions. This behavior of weed plants is very helpful for their successful invasion. Watanabe et al. (2002) reported similar behavior for invasive weed species. Seed germination of many weed species remained unaffected (from $\mathrm{pH} 4$ to 9) in various studies (Thomas et al., 2006; Chachalis et al., 2008; Wang et al., 2009). Germination of coolatai grass was $92 \%$ at $\mathrm{pH}$ level of 7.00, however at moderate level of $\mathrm{pH}$ (5.00) or (9.00) germination was reduced by around $10 \%$. Germination of coolatai grass was reduced at $\mathrm{pH}$ level of 4.00 or 10.00 (Chejara et al., 2008). Similar results to those of Chauhan et al. (2006f) were found in Lolium rigidum (rigid ryegrass). In contrast, 92 to $95 \%$ germination of Eleusine indica (goosegrass) was measured at a $\mathrm{pH}$ range between 4 and 10 (Chauhan \& Johnson, 2008d).

\section{Effect of salt stress}

Different salt stress levels exhibited significant effects on $A$. tenuifolius seed germination. It is clear from three parameter logistic model (Figure 4 and 5), that maximum $(88 \%)$ germination of $A$. tenuifolius was noted with $0 \mathrm{mM}$ (control) and it decreased significantly with a progressive increase in $\mathrm{NaCl}$ stress (from 50 to $150 \mathrm{mM}$ ) and the lowest (8\%) was recorded with $150 \mathrm{mM}$ salt stress. At $200 \mathrm{mM}$ of $\mathrm{NaCl}$ stress, germination of A. tenuifolius was completely inhibited. A $50 \%$ inhibition of $A$. tenuifolius maximum germination was noted at $80 \mathrm{mM}$ of salt stress (Figure 5).

Starting time of $A$. tenuifolius germination was statistically similar in 0 and $50 \mathrm{mM}$ of $\mathrm{NaCl}$. Greatest starting time of $A$. tenuifolius germination (10 days) was noted at $150 \mathrm{mM}$ of $\mathrm{NaCl}$ stress (Table 5). Asphodelus tenuifolius also took more days to get $50 \%$ germination (11.69 days) and mean germination time (11.42 days) with a $\mathrm{NaCl}$ stress level of $150 \mathrm{mM}$. However, 50 and $100 \mathrm{mM}$ of $\mathrm{NaCl}$ stress resulted statistically similar time to get $50 \%$

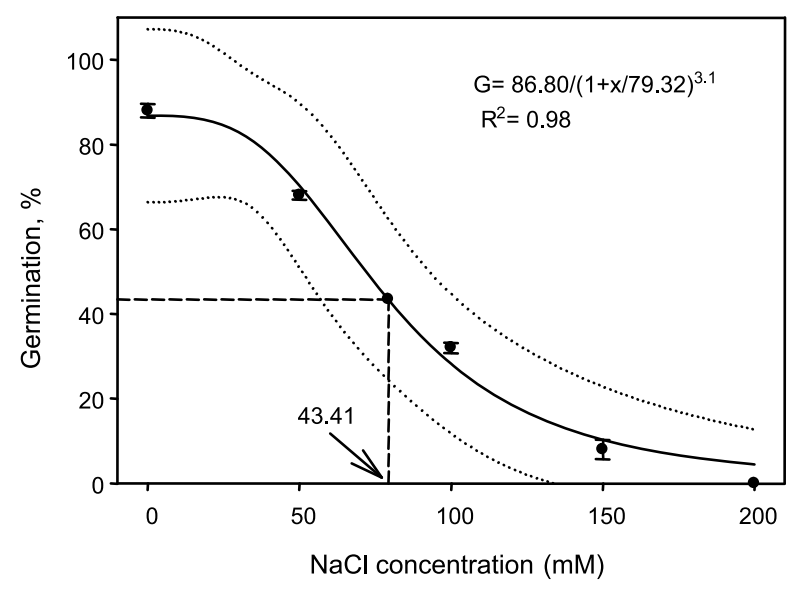

The bold lines represent a three-parameter logistic model fitted to the data and dotted lines show 95\% confidence intervals. Vertical bars represent \pm standard error of the mean. Vertical dash line represents $\mathrm{X}$-axis value at $50 \%$ of greatest germination.

Figure 5 - Effect of $\mathrm{NaCl}$ concentration (mM) on A. tenuifolius seed germination (\%). 
Table 5 - Effect of salt stress $(\mathrm{NaCl})$ on starting time of germination, time to $50 \%$ germination, mean germination time and germination index of $A$. tenuifolius

\begin{tabular}{|c|c|c|c|c|}
\hline Salt stress $(\mathrm{mM})$ & T-start \pm SE (days) & T-50 \pm SE (days) & MGT \pm SE (days) & GI \pm SE \\
\hline 0 (Control) & $2.00 \mathrm{c} \pm 0.00$ & $5.88 \mathrm{c} \pm 0.16$ & $6.58 \mathrm{c} \pm 0.11$ & $4.37 \mathrm{a} \pm 0.11$ \\
\hline 50 & $3.00 \mathrm{c} \pm 0.00$ & $10.17 \mathrm{~b} \pm 0.06$ & $9.86 \mathrm{~b} \pm 0.03$ & $1.95 \mathrm{~b} \pm 0.08$ \\
\hline 100 & $5.75 \mathrm{~b} \pm 0.85$ & $10.63 \mathrm{ab} \pm 0.30$ & $10.25 \mathrm{~b} \pm 0.45$ & $0.87 \mathrm{c} \pm 0.08$ \\
\hline 150 & $10.0 \mathrm{a} \pm 0.00$ & $11.69 \mathrm{a} \pm 0.89$ & $11.42 \mathrm{a} \pm 0.58$ & $0.17 \mathrm{~d} \pm 0.03$ \\
\hline 200 & $\mathrm{~N} / \mathrm{G}$ & $\mathrm{N} / \mathrm{G}$ & $\mathrm{N} / \mathrm{G}$ & $\mathrm{N} / \mathrm{G}$ \\
\hline $\mathrm{LSD} \leq 0.05$ & 1.32 & 1.46 & 1.15 & 0.25 \\
\hline
\end{tabular}

Values with same letters did not differ significantly at $\mathrm{P} \leq 0.05$. N/G non-germinated, T-start $=$ starting time of germination, $\mathrm{T}-50=$ time to $50 \%$ germination, $\mathrm{MGT}=$ mean germination time, $\mathrm{GI}=$ germination index and $\mathrm{SE}=$ standard error.

germination and MGT. Lowest time to get 50\% germination (5.88 days) and MGT (6.58 days) were recorded with control $(0 \mathrm{mM} \mathrm{NaCl})$.

However, with increase in salt stress from 0 to $150 \mathrm{mM}$, GI of $A$. tenuifolius decreased from 4.37 to 0.17 (Table 5). Our findings suggested that $A$. tenuifolius is very sensitive to salt stress, however a few seeds of $A$. tenuifolius were able to germinate even at high salt stress $(150 \mathrm{mM})$, which enables successful A. tenuifolius spread in saline areas around the country. Similar to A. tenuifolius, seeds of Mimosa invisa (Chauhan \& Johnson, 2008a) and Brassica tournefortii (Chauhan et al., 2006e) exhibited germination even at very high salt concentration.

Salts decreased water imbibition by seeds (Bae et al., 2006), inhibiting the germination of many species (Chauhan \& Johnson, 2008b). Nandula et al. (2006) found that germination of horse weed decreased with increasing $\mathrm{NaCl}$ concentration, and that only $4 \%$ germination of horse weed was found at $160 \mathrm{mM} \mathrm{NaCl}$. Similarly, an inverse or negative relationship in seed germination of american sloughgrass (Beckmannia syzigachne) (Rao et al., 2008) and Atriplex verrucifera (Peng-Peng \& Gui-Ling, 2008) was recorded with increased salt concentration.

\section{Effect of seeding depth}

Effect of varying seeding depths was significant on A. tenuifolius emergence. Greatest emergence of $A$. tenuifolius (79\%) was recorded with the seeds placed on soil surface and its emergence was gradually decreased with increase in seeding depth upto $4 \mathrm{~cm}$ (only $3 \%$ emergence). Emergence of $A$. tenuifolius was zero at $5 / 6 \mathrm{~cm}$ after 28 days of sowing (Figure 6). Starting time of $A$. tenuifolius emergence was non-significant among all the treatments. Greatest time to get $50 \% \mathrm{~A}$. tenuifolius emergence (9.56 days) and MET (9.52 days) was noted with the seeds placed at $3 \mathrm{~cm}$ depth and the lowest time to obtain 50\% germination and MET was recorded with A. tenuifolius placed at 2 and $1 \mathrm{~cm}$ depth $(5.06$ and 6.20 days, respectively) (Table 6).

Asphodelus tenuifolius showed greatest emergence index with the seeds placed at $1 \mathrm{~cm}$ (3.70) and it was statistically similar with

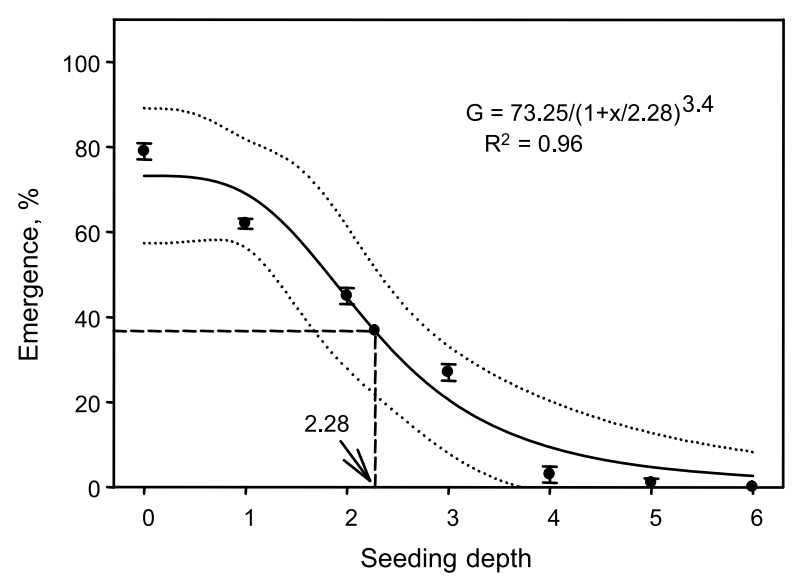

The bold lines represent a three-parameter logistic model fitted to the data and dotted lines show 95\% confidence intervals. Vertical dash line represents $\mathrm{X}$-axis value at $50 \%$ of greatest germination. Vertical bars represent \pm standard error of the mean.

Figure 6 - Effect of seeding depth on A. tenuifolius seed emergence (\%).

Planta Daninha, Viçosa-MG, v. 32, n. 1, p. 69-80, 2014 
Table 6 - Effect of seeding depth on starting time of emergence, time to 50\%.emergence, mean emergence time and emergence index of A. tenuifolius

\begin{tabular}{|c|c|c|c|c|}
\hline Seeding depth $(\mathrm{cm})$ & T-start \pm SE (days) & T-50 \pm SE (days) & MET \pm SE (days) & EI \pm SE \\
\hline 0 & $2.25 \pm 0.25$ & $5.88 \mathrm{ab} \pm 0.16$ & $6.97 \mathrm{ab} \pm 0.17$ & $3.64 \mathrm{a} \pm 0.09$ \\
\hline 1 & $2.00 \pm 0.00$ & $5.10 \mathrm{ab} \pm 0.16$ & $6.20 \mathrm{ab} \pm 0.19$ & $3.70 \mathrm{a} \pm 0.06$ \\
\hline 2 & $3.50 \pm 0.50$ & $5.06 \mathrm{ab} \pm 0.36$ & $6.83 \mathrm{ab} \pm 0.33$ & $2.01 \mathrm{~b} \pm 0.03$ \\
\hline 3 & $4.75 \pm 0.25$ & $9.56 \mathrm{a} \pm 0.33$ & $9.52 \mathrm{a} \pm 0.05$ & $0.82 \mathrm{c} \pm 0.07$ \\
\hline 4 & $4.50 \pm 2.63$ & $5.63 \mathrm{ab} \pm 3.33$ & $5.25 \mathrm{ab} \pm 3.04$ & $0.07 \mathrm{~d} \pm 0.05$ \\
\hline 5 & $\mathrm{~N} / \mathrm{N}$ & $\mathrm{N} / \mathrm{E}$ & $\mathrm{N} / \mathrm{E}$ & $\mathrm{N} / \mathrm{E}$ \\
\hline 6 & $\mathrm{~N} / \mathrm{N}$ & $\mathrm{N} / \mathrm{E}$ & $\mathrm{N}$ & $-\mathrm{E}$ \\
\hline $\mathrm{NSD} \leq 0.05$ & $\mathrm{NS}$ & 5.00 & 4.80 & 0.18 \\
\hline
\end{tabular}

Values with same letters did not differ significantly at $\mathrm{P} \leq 0.05$. NS $=$ non-significant, N/E $=$ not-emerged, T-start $=$ starting time of emergence, $\mathrm{T}-50=$ time to $50 \%$ emergence, $\mathrm{MET}=$ mean emergence time, $\mathrm{EI}=$ emergence index and $\mathrm{SE}=$ standard error.

soil surface placement (3.64). Emergence index of $A$. tenuifolius decreased progressively after $2 \mathrm{~cm}$ depth and lowest was recorded at $4 \mathrm{~cm}$ depth (0.07). A 50\% inhibition of A. tenuifolius greatest emergence occurred at $2.28 \mathrm{~cm}$. Greatest $A$. tenuifolius emergence at soil surface enables its successful distribution and increases its density to economic injury level throughout chickpea producing areas, because practice of no tillage is common in these areas. However, reasonable emergence of $A$. tenuifolius also occurred at 1,2 and $3 \mathrm{~cm}$ burial depths. Studies by Thomas et al. (2006) showed that seeds of Amaranthus viridis (Slender Amaranth) emerged in between 0.5 and $2 \mathrm{~cm}$. Contrary to the above findings, the emergence of threehorn bedstraw was negligible at soil surface and it increased with increasing burial depths up to $5 \mathrm{~cm}$ (Chauhan et al., 2006d). In contrast, seedling emergence of Sonchus oleraceus decreased with increasing seeding depth (Chauhan et al., 2006a).

Results of our laboratory experiments suggested that $A$. tenuifolius can tolerate a wide range of varying environmental factors which is a plus point of $A$. tenuifolius against its management. At $15{ }^{\circ} \mathrm{C}$, germination of A. tenuifolius was at its highest; however at 20 and $25^{\circ} \mathrm{C}$ considerable A. tenuifolius germination was measured. A. tenuifolius seeds exhibited greatest germination under light as compared with complete darkness. Increase in water stress significantly decreased $A$. tenuifolius germination. A considerable germination of $A$. tenuifolius occurred at all $\mathrm{pH}$ levels from 6.00 to 9.00, which the $\mathrm{pH}$ level of soils in almost all areas of Pakistan. Asphodelus tenuifolius is very sensitive to salinity; however a few seeds of A. tenuifolius were able to germinate even at $150 \mathrm{mM}$ of salt stress. Seeds of A. tenuifolius showed greatest emergence when planted at soil surface, however considerable number of seeds emerged at 1,2 and $3 \mathrm{~cm}$ burial depths. This fact suggests that for a successful management of A. tenuifolius in chickpea, a deep burial of its seeds at $5 \mathrm{~cm}$ or below is helpful. No tillage practice is common in chickpea growing areas, and that may explain the successful outcome of $A$. tenuifolius.

\section{LITERATURE CITED}

AOSA (ASSOCIATION OF OFFICIAL SEED ANALYSIS). Rules for testing seeds. J. Seed Technol., v. 12, n. 3, p. 1-112, 1990.

BAE, D. et al. Effect of salt $(\mathrm{NaCl})$ stress on germination and early seedling growth of four vegetables species. J. Central Eur. Agric., v. 7, n. 2, p. 199-220, 2006.

BARTLETT MS The use of transformations. Biometrics. v. 3, n. 1, p. 39-52. 1947.

BENVENUTI, S. et al. Germination ecology, emergence and host detection in Cuscuta campestris. Weed Res., v. 45, n. 4, p. 270-278, 2005.

BENVENUTI, S. et al. Germination ecology of Leptochloa chinensis: A new weed in the Italian rice agro-environment. Weed Res., v. 44, n. 2, p. 87-96, 2004. 
BHOWMIK P. C. Weed biology: importance to weed management. Weed Sci., v. 45, n. 3, p. 349-356, 1997.

CHACHALIS, D. et al. Factors affecting seed germination and emergence of venice mallow (Hibiscus trionum). Weed Sci., v. 56, n. 4, p. 509-515, 2008.

CHACHALIS, D.; REDDY, K. N. Factors affecting Campsis radicans seed germination and seedling emergence. Weed Sci. v. 48, n. 2, p. 212-216, 2000.

CHAUHAN, B. S.; JOHNSON, D. E. Seed germination and seedling emergence of synedrella (Synedrella nodiflora) in a tropical environment. Weed Sci., v. 57, n. 1, p. 36-42, 2009 b.

CHAUHAN, B. S.; JOHNSON, D. E. Germination ecology of spiny (Amaranthus spinosus) and slender amaranth (A. viridis): Troublesome weeds of direct-seeded rice. Weed Sci., v. 57, n. 4, p. 379-385, 2009c.

CHAUHAN, B. S.; JOHNSON, D. E. Seed germination and seedling emergence of giant sensitiveplant (Mimosa invisa). Weed Sci., v. 56, n. 2, p. 244-248, 2008a.

CHAUHAN, B. S.; JOHNSON, D. E. Germination ecology of southern crabgrass (Digitaria ciliaris) and indian crabgrass (Digitaria longiflora): Two important weeds of rice in tropics. Weed Sci., v. 56, n. 5, p. 722-728, 2008 b.

CHAUHAN, B. S.; JOHNSON, D. E. Influence of environmental factors on seed germination and seedling emergence of eclipta (Eclipta prostrata) in a tropical environment. Weed Sci., v. 56, n. 3, p. 383-388, 2008c.

CHAUHAN, B. S.; JOHNSON, D. E. Germination ecology of goosegrass (Eleusine indica): An important grass weed of rainfed rice. Weed Sci., v. 56, n. 5, p. 699-706, 2008d.

CHAUHAN, B. S.; JOHNSON. D. E. Seed germination ecology of purple-leaf button weed (Borreria ocymoides) and indian heliotrope (Heliotropium indicum): Two common weeds of rain-fed rice. Weed Sci., v. 56, n. 5, p. 670-675, 2008 e.

CHAUHAN, B. S.; GILL, G.; PRESTON, C. African mustard (Brassica tournefortii ) germination in southern Australia. Weed Sci., v. 54, n. 5, p. 891-897, 2006c.

CHAUHAN, B. S. et al. Factors affecting seed germination of annual sowthistle (Sonchus oleraceus) in southern Australia. Weed Sci., v. 54, n. 5, p. 854-860, 2006a.

CHAUHAN, B. S. et al. Seed germination and seedling emergence of threehorn bedstraw (Galium tricornutum). Weed Sci., v. 54, n. 5, p. 867-872, 2006 d.

CHEJARA, V. et al. Factors affecting germination of coolatai grass (Hyparrhenia hirta). Weed Sci., v. 56, n. 4, p. 543-548, 2008.
COOLBEAR, P. et al. The effect of low temperature presowing treatment on the germination performance and membrane integrity of artificially aged tomato seeds. J. Exper. Bot., v. 35, n. 11, p. 1609-1617, 1984.

DITOMMASO, A. Germination behavior of common ragweed (Ambrosia artemisiifolia) populations across a range of salinities. Weed Sci., v. 52, p. 1002-1009, 2004.

ELLIS, R. A.; ROBERTS. E. H. The quantification of aging and survival in orthodox seeds. Seed Sci. Technol., v. 9, n. 2, p. 373-409, 1981.

FRIED, G. et al. Environmental and management factors determining weed species composition and diversity in France. Agric. Ecos. Environ., v. 128, n. 1/2, p. 68-76, 2008.

GORAI, M. et al. Factors influencing seed germination of medicinal plant Salvia aegyptiaca L. (Lamiaceae). Saudi J. Biol. Sci., v. 18, n. 3, p. 255-260, 2011.

GUMA, I. R. et al. Effect of temperature and salinity on germination of Salsola vermiculata L. (chenopodiaceae) from Canary Islands. J. Arid Environ., v. 74, n. 6, p. 708-711, 2010.

HARRINGTON, T. B. Seed germination and seedling emergence of scotch broom (Cytisus scoparius). Weed Sci., v. 57, n. 6, p. 620-626, 2009.

HARRISON, S. et al. Seed size and burial effects on giant ragweed (Ambrosia trifida) emergence and seed demise. Weed Sci., v. 55, n. 1, p. 16-22, 2007.

HOLM, R. et al. World weeds, Natural Histories and distribution. New York: John Wiley and sons, 1977. p. 86.

INGOLIA, M. et al. Germination ecology of Rorippa subumbellata (Tahoe yellow cress), an endangered, endemic species of Lake Tahoe. Seed Sci. Technol., v. 36, n. 3, p. 621-632, 2008.

KABAT, S. M. et al. Temperature and light affects germination ecology of commercially produced seeds of leavenworth's coreopsis. Native Plants J., v. 8, n. 3, p. 236-247, 2007.

KOGER, C. H. et al. Factors affecting seed germination, seedling emergence and survival of texasweed (Caperonia palustris). Weed Sci., v. 52, n. 6, p. 989-995, 2004.

LU, P. et al. Effects of environmental factors on germination and emergence of crofton weed (Eupatorium adenophorum). Weed Sci., v. 54, n. 3, p. 452-457, 2006.

MALIK, M. S. et al. Temperature and light requirements for wild radish (Raphanus raphanistrum) germination over a 12-month period following maturation. Weed Sci., v. 58, n. 2, p. 136-140, 2010. 
MARTINKOVA, Z . et al. Seed age and storage conditions influence germination of barnyardgrass (Echinochloa crusgalli). Weed Sci., v. 54, n. 2, p. 298-304, 2006.

MASIN, R. et al. Temperature and water potential as parameters for modeling weed emergence in central-northern Italy. Weed Sci., v. 58, n. 3, p. 216-222, 2010.

MENNAN, H.; NGOUAJIO, M. Seasonal cycles in germination and seedling emergence of summer and winter populations of catchweed bedstraw (Galium aparine) and wild mustard (Brassica kaber). Weed Sci., v. 54, n. 1, p. 114-120, 2006.

MICHEL, B. E.; KAUFAMAN. M. R. The osmotic potential of polyethylene glycol 6000. Plant Physiol., v. 51, n. 5, p. 914-916, 1973.

NANDULA, V. K. et al. Factors affecting germination of horseweed (Conyza canadensis). Weed Sci., v. 54, n. 5, p. 898-902, 2006.

NASIR, Z. A.; SULTAN. S. Survey of weeds in mustard fields of district Chakwal, Pakistan. Pakistan J. Biol. Sci., v. 7, n. 2, p. 279-286, 2004.

NEMATI, I. et al. The effect of salinity stress on ions and soluble sugars distribution in leaves, leaf sheaths and roots of rice (Oryza sativa L.) seedlings. Plant Soil Environ., v. 57, n. 1, p. 26-33, 2011.

NORSWORTHY, J.; OLIVEIRA. M. Sicklepod (Senna obtusifolia) germination and emergence as affected by environmental factors and seeding depth. Weed Sci., v. 54, n. 5, p. 903-909, 2006.

PAHLEVANI, A. H. et al. Effects of environmental factors on germination and emergence of swallowwort. Weed Technol., v. 22, n. 2, p. 303-308, 2008.

PENG-PENG, L.; GUI-LING. Z. Germination and seeding growth of Atriplex verrucifera Bieb. Under $\mathrm{NaCl}$ stress. Acta Bot. Boreali-Occidentalia Sinica, v. 28, n. 12, p. 12, 2008.
PONIA, B. L. et al. Weed management in wheat (Triticum aestivum) with special reference to Asphodelus tenuifolius. Indian J. Weed Sci., v. 33, n. 3-4, p. 100-103, 2001.

RAO, N. et al. Influence of environmental factors on seed germination and seedling emergence of american sloughgrass (Beckmannia syzigachne). Weed Sci., v. 56, n. 4, p. 529-533, 2008.

SAS. Statistical Analysis Systems. SAS Procedures Guide. Version 9.0, Cary: Statistical Analysis Systems Institute, 2002.

STEEL, R. G. D. et al. Principles and procedures of statistics. Multiple comparisons. 3.ed. New York: McGraw Hill Book, 1997. p. 178-198.

THOMAS, W. et al. Influence of environmental factors on slender amaranth (Amaranthus viridis) germination. Weed Sci., v. 54, n. 2, p. 316-320, 2006.

TIWARI, A. N. et al. Crop-weed competition studies in chickpea having Asphodelus tenuifolius dominated weed community under rain fed condition. Indian J. Weed Sci., v. 33, n. 3\&4, p. 198-199, 2001.

WANG, J. J. et al. Factors affecting seed germination of cadillo (Urena lobata). Weed Sci., v. 57, n. 1, p. 31-35, 2009.

WATANABE, $\mathrm{H}$. et al. Environmental factors affecting germination of apple of Peru. Weed Sci., v. 50, n. 2, p. 152-156, 2002.

WIDDERICK, M. J. et al. Better management of Sonchus oleraceus L. (common sowthistle) based on the weed's ecology. In: AUSTRALIAN WEEDS CONFERENCE,14., 2004, Wagga. Proceedings... Wagga: New South Wales, Weed Society of New South Wales, 2004. p.535-537.

ZHOU, J. et al. Factors affecting germination of hairy nightshade (Solanum sarrachoides) seeds. Weed Sci., v. 53, n. 1, p. 41-45, 2005. 